\title{
Prematurity: Epidemiology and Etiological Factors in a Maternity Ward in Dakar (Senegal)
}

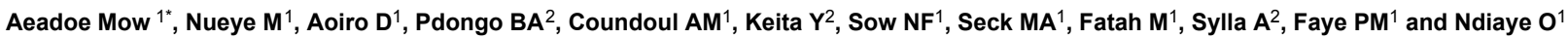 \\ ${ }^{1}$ Department of Pediatric, Abass Ndao National Hospital Center, Dakar, Senegal \\ ${ }^{2}$ Department of Pediatric, University Hospital Center (CHU) Aristide le Dantec, BP 3001 Dakar-Fann, Senegal
}

"Corresponding author: Aeadoe Mow, Department of Pediatric, Abass Ndao National Hospital Center, Dakar, Senegal, Tel: +221772690111, +221703064291; E-mail: amadousoow@hotmail.com

Received date: January 29, 2018; Accepted date: February 20, 2018; Published date: February 27, 2018

Copyright: @2018 Mow A, et al. This is an open-access article distributed under the terms of the Creative Commons Attribution License, which permits unrestricted use, distribution, and reproduction in any medium, provided the original author and source are credited.

\begin{abstract}
Background: Prematurity is the leading cause of neonatal mortality and morbidity in the world. Several etiological factors contribute to its occurrence requiring identification for effective prevention. The objective of this work was to study the epidemiological and etiological factors of prematurity in the maternity ward of the Grand YOFF General Hospital (GYGH) in Dakar.

Methods: This was a prospective study including all live and viable newborns conducted during January $1^{\text {st }}$ to August $31^{\text {st. }}$. They were divided into 2 groups: premature infants (22 WA-36 WA+6 days) and term infants (over 37 WA). Statistical comparisons were based on percentages for the chi-square test or Fisher's exact small sample test.

Results: During the study, 501 newborns were collected including 360 term neonates $(71.9 \%)$ and 141 premature babies $(28.1 \%)$. The sex ratio was 1.07 . Of the premature babies, $48.2 \%$ were hypotrophic. There were 13 cases of premature death $(9.22 \%)$. The occurrence of prematurity was significantly related to educational level, geographic origin and body mass index (BMI). The number of prenatal consultations (PNC) less than 3 was related to a risk of prematurity $(p=0.001)$. Genitourinary infections $(p=0.059)$, high blood pressure $(p=0.047)$, pre-eclampsia $(p=0.009)$, isolated anaemia $(p=0.0001)$ and isolated bleeding $(p=0.015)$ were found as significant etiological factors.
\end{abstract}

Conclusion: In our study, several etiological factors associated with prematurity were identified. Combating these factors is an effective way to prevent prematurity in our low-income countries.

Keywords: Prematurity; Etiologies; Maternity; Dakar; Senegal

\section{Introduction}

Prematurity is defined as any live birth between 22 weeks of amenorrhea (SA) and 37 years [1]. It is the leading cause of neonatal mortality and morbidity with more than one million annual deaths worldwide [2]. There are several etiological factors contributing to the occurrence of prematurity and their identification is necessary for effective prevention. In Senegal, the prevalence of prematurity is estimated at 9.7 per 1000 live births. However, these data are undervalued because of the difficulty of accurately determining gestational age [3]. The aim of this study was to study the epidemiological and etiological factors of prematurity in a maternity hospital in Dakar.

\section{Materials and Methods}

This was a prospective study conducted from January 1st to August $31^{\text {st }}, 2013$ in the maternity ward and the neonatology department of Grand Yoff General Hospital (GYGH). It is a level 3 public hospital with a high influx of people from Dakar and other parts of the country. Were Included all live and viable newborns. They were divided into 2 subgroups according to gestational age or week of amenorrhea (WA): group 1 or premature (22 WA-36 WA+6 days) and group 2 or term neonates (over $37 \mathrm{WA}$ ). The parameters studied in the neonates were gestational age, mode of delivery, anthropometric data, APGAR score, trophicity, neonatal complications, mortality and causes of death. In the mother we studied socio-demographic data, gynaecological obstetric history, prenatal consultations (PNC) and pathologies that occurred during pregnancy. The data collected were analyzed with SPSS Version 17 software. Statistical comparisons were based on percentages for the chi-square test or Fisher's exact small sample test.

\section{Results}

During the study period, 501 newborns were collected, including 360 term newborns $(71.9 \%)$ and 141 premature babies $(28.1 \%)$. The mean gestational age was $34.42 \mathrm{WA}$ (22 WA+4 days-36 WA) with a prevalence of the age range between $33 \mathrm{WA}$ and $36 \mathrm{WA}(83 \%)$. The sex ratio was 1.07. The average weight was $2900 \mathrm{~g}$ (900 g-3600 g), the average size $38.89 \mathrm{~cm}(33 \mathrm{~cm}-51 \mathrm{~cm})$; the average arm circumference $9.1 \mathrm{~cm}(6 \mathrm{~cm}-12 \mathrm{~cm})$ and the average cranial perimeter $30 \mathrm{~cm}(24$ $\mathrm{cm}-36 \mathrm{~cm})$.

Among premature babies, $48.2 \%$ had low birth weight. In $14.9 \%$ of cases, the APGAR score was between 4-6 and below 3 in $6.8 \%$ of cases. Of these premature babies, $25.53 \%$ were hospitalized in neonatology. The great prematurity and asphyxia were the main causes of transfer representing respectively $12.06 \%$ and $9.21 \%$. There were 13 cases of premature death $(9.22 \%)$. The causes of death were prematurity itself $(4.96 \%)$, asphyxia $(2.12 \%)$, haemorrhage $(2.12 \%)$ and neonatal 
Page 2 of 3

infections (0.70\%). Educational level, geographical origin and body mass index (BMI) were significantly related to the occurrence of prematurity. In our study, parity was not statistically significant.

\begin{tabular}{|c|c|c|c|}
\hline Settings & Prematurity & $\begin{array}{l}\text { Newborn } \\
\text { term }\end{array}$ & P-value \\
\hline \multicolumn{4}{|l|}{ Age (years) } \\
\hline$<21$ & $17(12.1 \%)$ & $27(7.5 \%)$ & \multirow[t]{3}{*}{0.153} \\
\hline $21-35$ & $83(58.9 \%)$ & $240(66.7 \%)$ & \\
\hline$>35$ & $41(29.1 \%)$ & $93(25.8 \%)$ & \\
\hline \multicolumn{4}{|l|}{ Level of education } \\
\hline Primary school & $53(37.6 \%)$ & 104 (29.9\%) & \multirow[t]{4}{*}{0.035} \\
\hline Secondary school & 45 (31.9\%) & $156(43.3 \%)$ & \\
\hline University & $17(21.1 \%)$ & $54(15.0 \%)$ & \\
\hline Never schooled & 26 (18.4\%) & $46(12.8 \%)$ & \\
\hline \multicolumn{4}{|l|}{ Geographic origin } \\
\hline Urban area & $37(26.2 \%)$ & 142 (39.4\%) & \multirow[t]{3}{*}{0.022} \\
\hline Semi urban & $101(71.6 \%)$ & $210(58.3 \%)$ & \\
\hline Rural area & $3(2.1 \%)$ & $8(2.2 \%)$ & \\
\hline \multicolumn{4}{|l|}{ Body mass index } \\
\hline$<18.59$ (thinness) & 20 (14.2\%) & $26(7.2 \%)$ & \multirow[t]{3}{*}{0.022} \\
\hline $18.60-25$ & 77 (54.6\%) & $186(52.5 \%)$ & \\
\hline$>25$ & $44(31.2 \%)$ & 145 (40.3\%) & \\
\hline
\end{tabular}

Table 1: Distribution of newborns according to maternal sociodemographic data.

\begin{tabular}{|c|c|c|c|}
\hline Settings & Prematurity & Newborn term & P-value \\
\hline \multicolumn{4}{|l|}{ Parity } \\
\hline One & $96(68.1 \%)$ & 209 (58.1\%) & \multirow[t]{3}{*}{0.106} \\
\hline Between 2- 4 & $32(27.7 \%)$ & $113(31.4 \%)$ & \\
\hline$>5$ & $13(9.2 \%)$ & $38(10.6 \%)$ & \\
\hline \multicolumn{4}{|c|}{ Gynaecological history } \\
\hline Fibroma & $7(5.0 \%)$ & $25(6.9 \%)$ & 0.415 \\
\hline Uterine cyst & $2(1.4 \%)$ & $9(2.5 \%)$ & 0.458 \\
\hline Uterine malformation & $0(0 \%)$ & $1(0.3 \%)$ & 0.531 \\
\hline \multicolumn{4}{|c|}{ Prenatal consultation (PNC) } \\
\hline$<3$ PNC & $36(25.5 \%)$ & $40(11.1 \%)$ & \multirow[t]{2}{*}{0.0001} \\
\hline$\geq 3$ PNC & $104(74.5 \%)$ & $320(88.9 \%)$ & \\
\hline
\end{tabular}

Table 2: Distribution of newborns by gynecopsychiatric history and prenatal consultation.
A PNC number of less than 3 was significantly associated with a high risk of prematurity $(25.5 \%$ vs. $11.1 \%, \mathrm{p}=0.001)$ while a number greater than 3 PNC appears protective $(74.5 \%$ vs. $88.9 \%, \mathrm{p}=0.001)$. Among the pathologies detected during pregnancy, many of them were associated with the occurrence of prematurity. These were genitourinary infections $(27.7 \%$ vs. $17.6 \%, \mathrm{p}=0.059)$, high blood pressure (HBP) $(23.4 \%$ vs. $15.8 \%, \mathrm{p}=0.047)$, pre-eclampsia $(8.5 \%$ vs. $3.9 \%, \mathrm{p}=0.009)$, the threat of preterm birth (TPB) $(5.7 \%$ vs. $1.1 \%$, $\mathrm{p}=0.03 \%)$, anaemia alone $(36.2 \%$ vs. $15.0 \%, \mathrm{p}=0.0001)$ and isolated haemorrhages $(10.6 \%$ vs. $4.7 \%, \mathrm{p}=0.015)$. The distribution of premature infants (group 1) and term infants (group 2) according to maternal socio-demographic parameters, gynaecological obstetric history, PNC and pathologies that occurred during pregnancy were summarized in the respective tables 1-3.

\begin{tabular}{|c|c|c|c|c|}
\hline Pathology detected & & Prematurity & $\begin{array}{l}\text { Newborn } \\
\text { term }\end{array}$ & $\begin{array}{l}P \text { - } \\
\text { value }\end{array}$ \\
\hline & Malaria & $6(4.3 \%)$ & $16(4.4 \%)$ & 0.924 \\
\hline & $\begin{array}{l}\text { Genitourinary } \\
\text { infection }\end{array}$ & $33(27.7 \%)$ & $56(17.6 \%)$ & 0.059 \\
\hline & Hepatitis B & $4(2.8 \%)$ & $5(1.4 \%)$ & 0.150 \\
\hline & HIV & $1(0.7 \%)$ & 0 & 0.150 \\
\hline & Rubella & 0 & $1(1.03 \%)$ & 0.150 \\
\hline & Syphilis & $1(0.7 \%)$ & 0 & 0.150 \\
\hline \multirow{3}{*}{$\begin{array}{l}\text { Hypertensive } \\
\text { diseases } \\
\text { complications }\end{array}$} & HBP & $33(23.4 \%)$ & $57(15.8 \%)$ & 0.047 \\
\hline & Pré-éclampsia & $12(8.5 \%)$ & $11(3.1 \%)$ & 0.009 \\
\hline & $\mathrm{RPH}$ & $3(2.1 \%)$ & $2(0.6 \%)$ & 0.111 \\
\hline \multirow{6}{*}{$\begin{array}{l}\text { Other } \\
\text { Complications }\end{array}$} & TPB & $8(5.7 \%)$ & $4(1.1 \%)$ & 0.03 \\
\hline & Anemia & $51(36.2 \%)$ & $54(15.0 \%)$ & 0.0001 \\
\hline & Heart disease & $2(1.4 \%)$ & $2(0.6 \%)$ & 0.329 \\
\hline & Diabetes & $3(2.1 \%)$ & $5(1.4 \%)$ & 0.553 \\
\hline & $\begin{array}{l}\text { Isolated } \\
\text { hemorrhage }\end{array}$ & $15(10.6 \%)$ & $17(4.7 \%)$ & 0.015 \\
\hline & Placenta prævia & $1(0.7 \%)$ & $2(0.6 \%)$ & 0.841 \\
\hline
\end{tabular}

HBP: High Blood Pressure; RPH: Retro Placental Hematoma; TPB: Threatened Preterm Birth; HIV: Human Immunodeficiency Virus

Table 3: Distribution of newborns according to pathologies associated with pregnancy.

\section{Discussion}

The prevalence of premature birth in GYGH is comparable to data from Senegalese hospital literature. Indeed, Diagne [4] found a percentage of $27.20 \%$ and Sarr [5] 28.86\%. According to the World Health Organization (WHO), there is an average of $12 \%$ of premature births in poor countries compared with $9 \%$ in higher income countries [2]. The high prevalence in our study compared to this rate is explained by the fact that GYGH is a reference structure for neonatal care. Our results show that the risk of occurrence of prematurity is statistically related to educational level and geographic origin. Indeed, according to Balaka et al. insufficient monitoring of pregnancy and low level of 
education are strongly associated with a high risk of prematurity [6]. Several factors may explain this: high unemployment, low educational attainment, low socio-economic status, difficult living and working conditions, poor access to care, ignorance and unwanted pregnancies. Our study found a correlation between BMI and prematurity. Maternal thinness is significantly related to the occurrence of prematurity. This is due to a lack of micronutrients, especially iron and folic acid $[7,8]$. This work also reveals that a number of PCN below 3 is significantly associated with the risk of occurrence of prematurity. These results are confirmed by most data in the literature $[9,10]$. In light of these results, we can say that the number of PCN performed plays a key role in the monitoring of pregnancy in particular on the occurrence of prematurity. The interest lies in better care for pregnant women. The occurrence of prematurity is significantly related to genitourinary infections. In the Pambou et al. study, they represent one of the risk factors most frequently associated with prematurity. These infections should be routinely screened during pregnancy [11]. The risk factors remain dominated in our study as elsewhere by HBP, pre-eclampsia and retro placental hematoma (RPH) [9,12]. Thus, blood pressure disorders during pregnancy are still a major cause of maternal and perinatal mortality in several regions of the world, especially in Africa, where the diagnosis is often late $[9,13]$. Thus it is essential to monitor blood pressure and to look for proteinuria during PNC [14]. The risks of preterm birth are 2.5 or even 3 times higher in women with iron deficiency anaemia, especially in our poor countries [13]. Anne have established in their work a significant link between TPB and the risk of occurrence of preterm birth [15] as found in our study.

\section{Conclusion}

In our study, several etiological factors associated with prematurity were identified. This is a low level of education, leanness, number of PNC below 3, genitourinary infections, HBP, pre-eclampsia, TPB, anaemia and isolated bleeding. Combating these factors is an effective way to prevent prematurity in our low-income countries.

\section{Conflict of Interest}

All authors declare no conflicts of interest.

\section{References}

1. Lacaze MT, Zupan V, Dehan M (2000) L'entrée dans la vie prématurément. Médecine science 16: 345-353.
2. Blencowe H, Cousens S, Oestergaard M, Chou D, Moller AB, et al. (2012) National, regional and worldwide estimates of preterm birth. Lancet 379: 2162-2172.

3. Liu L, Johnson HL, Cousens S, Perin J, Scott S, et al. (2012) Global, regional, and national causes of child mortality: an updated systematic analysis for 2010 with time trends since 2000. Lancet 379: 2151-2161.

4. Diagne NR (2000) Caractéristiques périnatales et devenir du prématuré : à propos de 277 cas à l'unité de néonatologie de l'hôpital d'enfant Albert Royer de Dakar (Sénégal). Th Med Dakar: N12.

5. Sarr El HM (2010) Epidémiologie de la prématurité au service de néonatologie du centre hospitalier Abass Ndao de Dakar (Sénégal). Th Med Dakar: N120.

6. Balaka B, Baeta S, Agbere AD, Boko K, Kessie K, et al. (2002) Facteurs de risque associés à la prématurité au CHU de Lomé, Togo. Bull Soc Pathol Exot 95: 280-283.

7. Shankar A, Jaharri A, Sebayang S, Aditiawarman, Apriatni M, et al. (2008) Effect of maternal multiple micronutrient supplementation on fetal loss and infant death in Indonesia: a double-blind clusterrandomised trial. Lancet 371: 215-227.

8. Zagre NM, Desplats G, Adou P, Mamadoultaibou A, Aguayo VM (2007) Prenatal multiple micronutrient supplementation has greater impact on birth weight than supplementation with iron and folic acid: a clusterrandomized, double-blind, controlled programmatic study in rural Niger. Food Nutr Bull 28: 317-327.

9. Cisse CAT, Diaw TC, Sow S, Bnouhoud M, Dina G, et al. (1998) Accouchement prématuré: épidémiologie et pronostic au CHU de Dakar. J Gynecol Obstet Biol Reprod 27: 71-76.

10. Ndiaye O, Fall AL, Drame A, Sylla A, Gueye M, et al. (2006) Facteurs étiologiques de la prématurité au centre hospitalier régional de Ziguinchor Sénégal. Bull Soc Patho Exot 99: 113-114.

11. Pambou O, Ntsika-Kaya P, Ekoundzola JR, Mayanda F (2006) Naissances avant terme au CHU de Brazzaville. Cahier Sante 16: 185-189.

12. Lacroze V Prématurité (2015) définition, épidémiologie, étiopathogénie, organisation des soins. J de pédiatrie et de puériculture 28: 47-55.

13. Ye D, Kam KL, Sanou I, Traore A, Koueta F, et al. (1999) Etude épidémiologique et évaluative de la prématurité dans l'unité de néonatologie du CHN YO de Ouagadougou. Ann Pediatr 46: 643-648.

14. Toure IA, Brah F, Prual A (1997) Hypertension artérielle et grossesse au Niger: études cas/témoins à propos de 70 cas. Med Afr Noire 44.

15. Anne B (2011) Menace d’accouchement prématuré : circonstances d'hospitalisation et pronostic de la grossesse. HAL Gyn'ecologie et obst 'etrique. 